\title{
PENGARUH KOMITMEN ORGANISASI DAN KEPUASAN KERJA TERHADAP INTENSI TURNOVER PADA KARYAWAN PT. SINAR ANTJOL
}

\author{
Fadliya Siti Aisyia \\ Liaamoy ashari@yahoo.com \\ HIMPSI Provinsi Jawa Tengah
}

\begin{abstract}
Turnover, to employees, is one of wayouts to get better situation. But to employers, this can be loss. This study examined effect of organizational commitment which predicting variables are affective commitment, normative commitment, and continuous commitment. And job satisfaction which predicting variables are salary, promotion, supervision, remuneration, reward, work condition, coworker, nature of work, communication towards turnover intention. Sample size of this research is 204 using nonprobability sampling technique.
\end{abstract}

Keywords: organizational commitment, job satisfaction, turnover intention

\begin{abstract}
Abstrak
Turnover bagi karyawan merupakan salah satu jalan keluar untuk mendapatkan keadaan yang lebih baik, namun bagi perusahaan hal ini dapat menjadi suatu kerugian tersendiri. Penelitian ini menguji pengaruh komitmen organisasi yang mempunyai variabel prediksi yaitu komitmen afektif, komitmen normatif, serta komiten kontinuans dan kepuasan kerja yang mempunyai variabel prediksi yaitu upah/gaji, promosi, atasan, balas jasa, penghormatan/penghargaan, kondisi operasi/kondisi kerja, rekan kerja, sifat pekerjaan, dan komunikasi terhadap intensi turnover. Penelitian ini memiliki jumlah sampel sebanyak 204 orang yang diambil dengan teknik pengambilan sampel nonprobability sampling.
\end{abstract}

Kata kunci: komitmen organisasi, kepuasan kerja, intensi turnover 


\section{PENDAHULUAN}

Turnover dapat merugikan perusahaan baik dari segi biaya, sumber daya,maupun motivasi karyawan. Turnover yang terjadi berarti perusahaan kehilangan sejumlah tenaga kerja. Kehilangan ini harus diganti dengan karyawan baru, perusahaan harus mengeluarkan biaya mulai dari memasang iklan lowongan kerja, proses seleksi, pelatihan tenaga kerja baru hingga mendapatkan tenaga kerja siap pakai. Keluarnya karyawan berarti ada posisi tertentu yang lowong dan harus segera diisi. Tak jarang juga, karyawan yang tertinggal harus mengambil alih tugas pekerjaan yang lowong tersebut. Tenaga kerja yang ada terkadang tidak sesuai dengan tugas yang ada sehingga menjadi terbengkalai. Karyawan yang menetap akan terpengaruh motivasi dan semangat kerjanya. Karyawan yang sebelumnya tidak berusaha mencari pekerjaan baru akan mulai mencari lowongan kerja, yang kemudian akan berujung dengan terjadinya turnover (Janssen, 1998).

Mobley (1979) mendefinisikan turnover sebagai pemberhentian keanggotaan dalam sebuah organisasi oleh seseorang yang menerima kompensasi moneter karna telah berpartisipasi di dalam organisasi tersebut. Intensi keluar (intensi turnover) merupakan variabel yang paling berhubungan dan lebih banyak menjelaskan perilaku turnover (Mobley et al., 1979). Turnover lebih mengarah pada kenyataan akhir yang dihadapi organisasi pada periode tertentu. Sedang intensi keluar (intensi turnover) mengacu kepada hasil evaluasi individu mengenai kelanjutan hubungannya dengan organisasi dan belum diwujudkan dalam tindakan nyata meninggalkan organisasi atau hanya sebatas keinginan atau niat untuk meninggalkan organisasi.

Perusahaan yang memiliki angka turnover yang tinggi mengindikasikan bahwa karyawan merasa tidak betah atau tidak puas bekerja di perusahaan. Ketidakpuasan dan kekecewaan karyawan terhadap pekerjaannya menyebabkan karyawan tersebut datang terlambat, tidak masuk kerja, menghindari sebagian tanggung jawab kerja mereka, bahkan mengundurkan diri dari perusahaan. Namun jika karyawan merasa puas dengan pekerjaan dan perusahaannya, maka karyawan akan tetap bekerja di perusahaan tersebut yang pada akhirnya memberikan banyak keuntungan bagi perusahaan (Janssen, 1998).

Mobley (dalam Kathri, 1999) menyatakan bahwa terdapat hubungan yang negatif diantara kepuasan kerja dan intensi turnover, namun kepuasan kerja sendiri

hanya memiliki sedikit pengaruh terhadap turnover. Hasil penelitian yang menyatakan bahwa hubungan antara kepuasan kerja dan turnover tidak terlalu kuat bukan berarti penelitian mengenai kepuasan tidak disarankan. Hal tersebut menyarankan agar pengukuran mengenai kepuasan harus dikombinasikan dengan pengukuran lain untuk memahami dan memprediksi turnover secara efektif.

Selain dipengaruhi oleh kepuasan kerja, keinginan untuk mengakhiri pekerjaan atau meninggalkan perusahaan juga dipengaruhi oleh komitmen organisasi (Robbins, 2013). Komitmen organisasi merupakan suatu perasaan dimana karyawan itu menjadi bagian dari suatu organisasi dan melibatkan diri dalam organisasi tersebut, serta tidak ada keinginan meninggalkannya. Organisasi yang mampu memberikan perhatian yang penuh dan membuat karyawan percaya terhadap organisasi akan memperoleh komitmen karyawan. Komitmen karyawan terhadap organisasi akan membuat karyawan setia pada organisasi dan bekerja dengan baik untuk kepentingan organisasi. 


\section{TEORI DAN HIPOTESIS}

\section{Intensi Turnover}

Mobley (1986) menyatakan keinginan (intensi) untuk keluar dari organisasi merupakan prediktor dominan yang bersifat positif terhadap terjadinya turnover. Ia memberikan batasan turnover sebagai berhentinya individu dari anggota suatu organisasi dengan disertai pemberian imbalan keuangan oleh organisasi yang bersangkutan.

Tidak seperti perilaku turnover sebenarnya, intensi turnover tidaklah eksplisit. Intensi (niat) adalah pernyataan tentang ketertarikan atas perilaku tertentu. Intensi turnover merupakan cerminan dari kemungkinan seseorang untuk berpindah kerja dalam suatu periode tertentu, dan merupakan pertanda langsung terhadap perilaku turnover sesungguhnya. Mobley (1979) menyatakan bahwa intensi turnover menangkap persepsi dan evaluasi yang dilakukan individu terhadap suatu alternatif pekerjaan. Konsekuensi utama dari kepuasan kerja adalah rangsangan berfikir untuk berhenti dari pekerjaan, kemudian menuntun ke intensi untuk mencari apa yang diinginkan (dipengaruhi oleh evaluasi terhadap pekerjaan alternatif, sebelumnya dipertimbangkan umur dan masa jabatan), kemudian intensi untuk berhenti, yang akhirnya keputusan dan perilaku turnover (Mobley, 1979).

Menurut Zeffane (1994), intensi turnover adalah niat karyawan untuk berhenti bekerja dari pekerjaannya. Intensi Turnover adalah proses kognitif yang meliputi berpikir, berencana dan berkeinginan untuk berhenti dari suatu pekerjaan (Mobley, Griffeth, Hand, \& Meglino, 1979).

Dalam model turnover Mobley (1979) ada 4 kategori aspek kognitif pokok di dalam intensi turnover:

\section{a. Thinking of quitting (berpikir untuk keluar)}

Berpikir untuk keluar merupakan konsekuensi utama dari beberapa faktor seperti kepuasan kerja yang membuat seorang karyawan merasa ingin berhenti dari pekerjaannya.

b. Planning to stay or leave (merencanakan untuk tinggal atau keluar). Merencanakan untuk tinggal atau keluar merupakan langkah selanjutnya dari berpikir untuk keluar (thingking of quitting). Seorang pekerja akan melakukan evaluasi terhaap pekerjaan yang saat ini sedang dijalaninya, termasuk baik-buruk jika ia tetap bekerja pada peruahaan maupun baik-buruk jika ia keluar dari perusahaan tersebut.

c. Intention to search (intensi untuk mencari)

Pada tahap intensi untuk mencari, seorang individu akan mencari apa yang sesungguhnya ia inginkan. Hal ini dipengaruhi oleh alternatif pekerjaan lain yang tersedia, seorang karyawan akan membandingkan antara pekerjaannya saat ini dengan alternatif perkerjaan lain yang tersedia.

d. Intention to quit (intensi untuk keluar) 
Intensi untuk berhenti dianggap sebagai prekursor langsung dari intensi turnover, dengan perilaku impulsif dan jarak waktu yang tipis antara intensi dan perilaku turnover langsung dalam hubungan ini.

\section{Kepuasan Kerja}

Spector (1994) mendefinisikan kepuasan kerja sebagai sikap yang merefleksikan bagaimana perasaan evaluatif individu mengenai pekerjaannya, baik secara keseluruhan maupun dari berbagai aspek pekerjaannya. Perasaan tersebut berkisar antara kesukaan atau kepuasan terhadap pekerjaannya ataupun ketidaksukaan atau ketidakpuasan terhadap pekerjaannya. Selanjutnya Howel dan Dipboye (dalam Munandar, 2001) mendefinisikan kepuasan kerja sebagai hasil keseluruhan dari derajat rasa suka atau tidak sukanya tenaga kerja terhadap berbagai aspek dari pekerjaannya. Dengan kata lain kepuasan kerja mencerminkan sikap tenaga kerja terhadap pekerjaannya.

Menurut Robbins (2013), kepuasan kerja adalah sikap umum terhadap pekerjaan seseorang, yang menunjukkan perbedaan antara jumlah penghargaan yang diterima pekerja dan jumlah yang mereka yakini seharusnya mereka terima. Pendapat yang sama dikemukakan oleh Organ dan Hamner (1982) yang menjelaskan bahwa kepuasan kerja merupakan sikap seseorang terhadap pekerjaannya. Hal ini merupakan kumpulan kompleks kognisi (keyakinan atau pengetahuan), emosi (perasaan, sentiment, atau evaluasi), dan kecenderungan perilaku. Seseorang dengan tingkat kerpuasan kerja yang tinggi memiliki sikap yang sangat positif tentang pekerjaannya, dan sebaliknya orang yang merasa tidak puas dengan pekerjaanya akan memiliki sikap negatif terhadap pekerjaannya tersebut.

Penelitian dari Paul Spector's (1994) yang dikenal sebagai The Job Satisfaction Survey (JSS) mendefinisikan kepuasan sebagai kelompok perasaan evaluatif tentang pekerjaan. JSS menilai 9 aspek dari kepuasan kerja yang terdiri dari 36 item. Adapun kesembilan aspek tersebut yaitu:

1. Pay: jumlah dan rasa keadilannya

2. Promotion: peluang dan rasa keadilan untuk mendapatkan promosi

3. Supervision: keadilan dan kompetensi penugasan menajerial oleh atasan

4. Benefit: tunjangan, asuransi, liburan dan bentuk fasilitas yang lain

5. Contingent rewards: rasa hormat, diakui dan diberikan apresiasi

6. Operating procedures: kebijakan, prosedur dan aturan

7. Coworkers: rekan kerja yang menyenangkan dan kompeten

8. Nature of work: tugas itu sendiri dapat dinikmati atau tidak

9. Communication: berbagai informasi didalam organisasi (verbal maupun nonverbal)

3. Komitmen Organisasi

Allen dan Meyer (1990) mendefinisikan komitmen organisasi sebagai sebuah konsep yang memiliki tiga dimensi, yaitu affective, normative, dan continuance commitment. Affective commitment adalah tingkat seberapa jauh seorang karyawan secara emosi terikat, mengenal, dan terlibat dalam organisasi. Continuance commitment adalah suatu penilaian terhadap biaya yang terkait dengan meninggalkan organisasi. Normative commitment menunjukkan kepada tingkat seberapa jauh seseorang secara psikologis terikat untuk menjadi karyawan dari sebuah organisasi yang didasarkan kepada perasaan seperti kesetiaan, affeksi, kehangatan, pemilikan, kebanggaan, kesenangan, 
kebahagiaan, dll. Sementara itu, pendapat yang hampir sama mengenai definisi komitmen organisasi dikemukakan oleh Caldwell, Chatman dan O'Reilly (Singh et al., 2008) yang menyatakan bahwa komitmen organisasi merupakan ikatan psikologis antara karyawan dan organisasi. Berdasarkan Meyer dan Allen's (1990) terdapat tiga komponen dari komitmen yang merupakan karakteristik komitmen karyawan pada organisasi, yaitu:

\section{Affective Commitment}

Komitmen afektif didefinisikan sebagai emosi attachment yang positif pada organisasi. Pekerja yang memiliki komitmen yang kuat mengidentifikasikan organisasi dan keinginan untuk tetap menjadi bagian dari organisasi. Dengan demikian, karyawan yang memliki komitmen afektif yang kuat akan terus bekerja dalam organisasi karena mereka memang ingin (want to) melakukan hal tersebut.

\section{Continuance Commitment}

Komitmen kontinuans berkaitan dengan an awareness of the costs associated with leaving the organization. Hal ini menunjukkan adanya pertimbangan untung rugi dalam diri karyawan berkaitan dengan keinginan untuk tetap bekerja atau justru meninggalkan organisasi. Komitmen kontinuans sejalan dengan pendapat Becker yaitu bahwa komitmen kontinuans adalah kesadaran akan ketidakmungkinan memilih identitas sosial lain ataupun alternatif tingkah laku lain karena adanya ancaman akan kerugian besar. Karyawan yang terutama bekerja berdasarkan komitmen kontinuans ini bertahan dalam organisasi karena mereka butuh (need to) melakukan hal tersebut karena tidak adanya pilihan lain.

\section{Normative Commitment}

Komitmen normatif merefleksikan a feeling of obligation to continue employment. Dengan kata lain, komitmen normatif berkaitan dengan perasaan wajib untuk tetap bekerja dalam organisasi. Ini berarti, karyawan yang memiliki komitmen normatif yang tinggi merasa bahwa mereka wajib (ought to) bertahan dalam organisasi. Wiener (dalam Allen \& Meyer, 1990) mendefinisikan komponen komitmen ini sebagai tekanan normatif yang terinternalisasi secara keseluruhan untuk bertingkah laku tertentu sehingga memenuhi tujuan dan minat organisasi. Oleh karena itu, tingkah laku karyawan didasari pada adanya keyakinan tentang "apa yang benar" serta berkaitan dengan masalah moral.

\section{Hipotesis Penelitian \\ Hipotesis Mayor}

Kepuasan kerja dan komitmen organisasi memiliki pengaruh yang signifikan terhadap intensi turnover pada karyawan.

\section{Hipotesis Minor}

1. Komitmen organisasi memiliki pengaruh yang signifikan terhadap intensi turnover pada karyawan. 
2. Upah/Gaji memiliki pengaruh yang signifikan terhadap intensi turnover pada karyawan.

3. Promosi memiliki pengaruh yang signifikan terhadap intensi turnover pada karyawan.

4. Atasan memiliki pengaruh yang signifikan terhadap intensi turnover pada karyawan.

5. Balas jasa memiliki pengaruh yang signifikan terhadap intensi turnover pada karyawan.

6. Penghargaan memiliki pengaruh yang signifikan terhadap intensi turnover pada karyawan.

7. Kondisi kerja memiliki pengaruh yang signifikan terhadap intensi turnover pada karyawan.

8. Rekan kerja memiliki pengaruh yang signifikan terhadap intensi turnover pada karyawan.

9. Sifat pekerjaan memiliki pengaruh yang signifikan terhadap intensi turnover pada karyawan.

10. Komunikasi memiliki pengaruh yang signifikan terhadap intensi turnover pada karyawan.

\section{Metode Penelitian}

Populasi dalam penelitian ini adalah seluruh karyawan pada PT. Sinar Antjol Tangerang yang berjumlah 350 orang. Alasan peneliti mengambil populasi pada karyawan PT. Sinar Antjol adalah dikarenakan saat ini PT. Sinar Antjol ini sedang mengalami turnover (pergantian karyawan) yang cukup tinggi. Sedangkan sampel dalam penelitian ini berjumlah sebanyak 204 responden. Teknik pengambilan sampel dalam penelitian ini menggunakan teknik nonprobability sampling dengan karakteristik responden penelitian ini adalah karyawan tetap dengan masa kerja minimal 6 bulan.

Alat ukur intensi turnover dikembangkan berdasarkan teori Intensi Turnover Mobley (1978) yang mengemukakan bahwa terdapat empat bagian kognitif dari intensi turnover, yaitu: 1) berpikir untuk keluar (thinking of quitting);

2) merencanakan untuk tinggal atau keluar (planning to stay or leave); 3) mencari alternatif pekerjaan lain (searching for alternative employment/intention to search); and 4) keinginan untuk keluar dari pekerjaan yang saat ini dijalani (a desire to leave current job/intention to quit). Masing-masing diukur dengan menggunakan satu item, sehingga total item skala intensi turnover berjumlah empat.

Alat ukur kepuasan kerja. Alat ukur yang digunakan dalam penelitian ini adalah Paul Spector's Job Satisfaction Survey yang memiliki sembilan aspek kepuasan kerja. Skala ini terdiri dari 36 item yang mengukur sembilan dimensi.

Alat ukur komitmen organisasi. Alat ukur yang digunakan dalam penelitian ini adalah Organizational Commitment Scale (OCS). Alat ukur ini memiliki tiga aspek yang dikembangkan oleh Allen dan Meyer yang pada penelitian ini digunakan sebagai indikator. Total item untuk skala ini adalah sebanyak 10 item. 
Hasil Penelitian

Tabel 1 . Anova IV ANOVA $^{\text {b }}$

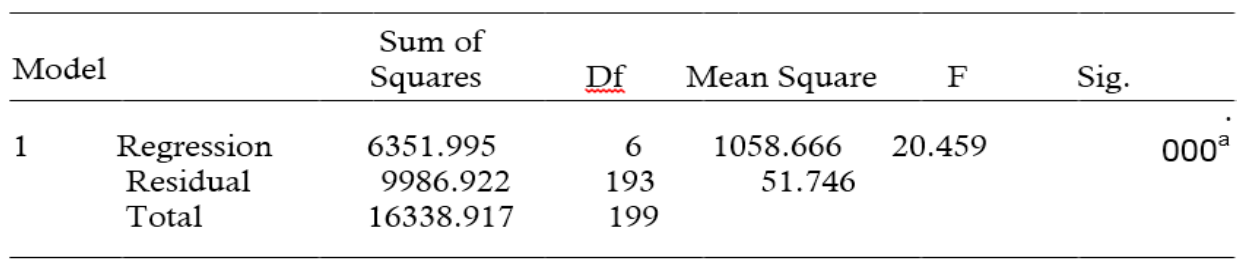

a. Predictors: (Constant), BB, NB, MC, PCB, EO, CB

b. Dependent Variable: INTENSI

Jika melihat Tabel 1. pada kolom ke-6 dari kiri $(\mathrm{p}<0.05)$, maka hipotesis nihil yang menyatakan tidak ada pengaruh yang signifikan seluruh IV terhadap intensi turnover, ditolak. Artinya ada pengaruh yang signifikan komitmen organisasi dan kepuasan kerja (pay, promotion, supervision, fringe benefit, contingent rewards, operating procedures, coworker, nature of work, dan communication) terhadap intensi turnover.

Tabel 2

Tabel Koefisien Regresi IV

\begin{tabular}{|c|c|c|c|c|c|c|}
\hline & \multirow[t]{2}{*}{ Mode1 } & \multicolumn{2}{|l|}{$\begin{array}{l}\text { Unstandardized } \\
\text { Coefficients }\end{array}$} & $\begin{array}{l}\text { Standardized } \\
\text { Coefficients }\end{array}$ & \multirow[t]{2}{*}{$t$} & \multirow[t]{2}{*}{ sig } \\
\hline & & $\mathrm{B}$ & Std. Error & Beta & & \\
\hline \multirow[t]{11}{*}{1} & (Constant) & .000 & .074 & & -.008 & .993 \\
\hline & upah & .248 & .119 & .210 & 2.076 & .039 \\
\hline & promosi & .010 & .062 & .014 & .158 & .874 \\
\hline & atasan & .084 & .104 & .076 & .803 & .423 \\
\hline & balas & -.939 & .391 & -.701 & -2.403 & .017 \\
\hline & penghargaan & .168 & .112 & .162 & 1.497 & .136 \\
\hline & kondisi & -.060 & .112 & -.058 & -.537 & .592 \\
\hline & rekan & .172 & .141 & .112 & 1.217 & .225 \\
\hline & sifat & -.021 & .108 & -.022 & -.192 & .848 \\
\hline & komunikasi & -.193 & .084 & -.175 & -2.289 & .023 \\
\hline & komitmen & .029 & .103 & .023 & .280 & .780 \\
\hline
\end{tabular}

Tabel 2

Tabel Koefisien Regresi IV

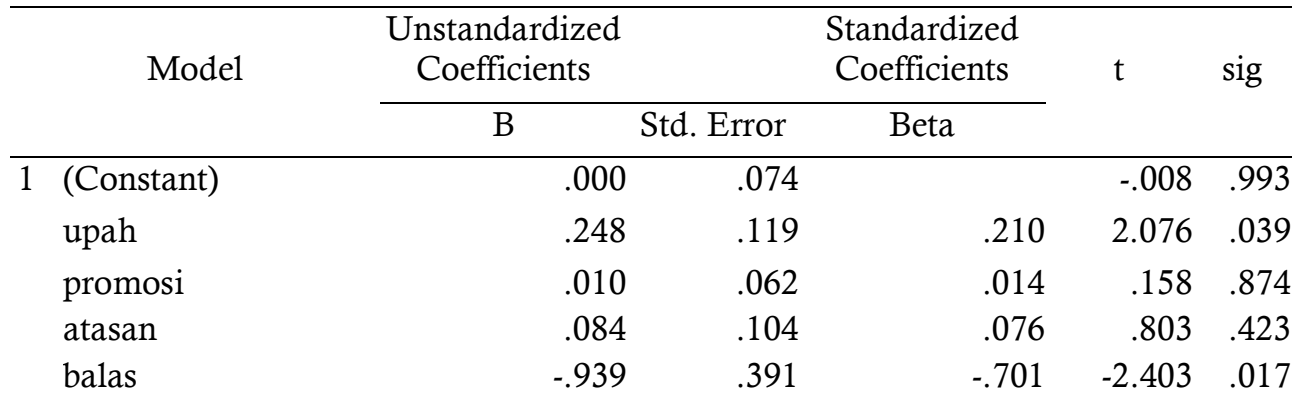




\begin{tabular}{lrrrrr}
\hline penghargaan & .168 & .112 & .162 & 1.497 & .136 \\
kondisi & -.060 & .112 & -.058 & -.537 & .592 \\
rekan & .172 & .141 & .112 & 1.217 & .225 \\
sifat & -.021 & .108 & -.022 & -.192 & .848 \\
komunikasi & -.193 & .084 & -.175 & -2.289 & .023 \\
komitmen & .029 & .103 & .023 & .280 & .780 \\
\hline
\end{tabular}

Dari Tabel 2 di atas, untuk melihat signifikan atau tidaknya koefisien regresi yang dihasilkan, cukup melihat pada nilai signifikan pada kolom ke-6. Jika signifikan < 0.05 , maka koefisien regresi yang dihasilkan, signifikan pengaruhnya terhadap intensi turnover dan sebaliknya. Dari hasil di atas hanya koefisien regresi variabel komunikasi, variabel upah dan variabel balas jasa yang siginifkan, sedangkan sisa lainnya tidak. Hal ini berarti bahwa dari 10 hipotesis minor hanya tiga yang signifikan. Adapun penjelasan dari nilai koefisien regresi yang diperoleh pada masing-masing IV adalah sebagai berikut:

1. Dimensi upah memiliki nilai koefisien sebesar 0.248 dengan nilai $\mathrm{P}=0.039$, yang artinya bahwa dimensi upah secara positif mempengaruhi intensi turnover dan signifikan. Jadi, semakin tinggi skor upah maka semakin tinggi intensi turnover.

2. Dimensi promosi memiliki nilai koefisien sebesar 0.010 dengan nilai $P=0.874$, yang artinya bahwa dimensi promosi secara positif mempengaruhi intensi turnover. Jadi, semakin tinggi skor promosi maka semakin tinggi intensi turnover.

3. Dimensi atasan memiliki nilai koefisien sebesar 0.084 dengan nilai $\mathrm{P}=0.423$, yang artinya bahwa dimensi atasan secara positif mempengaruhi intensi turnover. Jadi, semakin tinggi skor atasan maka semakin tinggi intensi turnover.

4. Dimensi balas jasa memiliki nilai koefisien sebesar -0.939 dengan nilai $\mathrm{P}=0.017$, yang artinya bahwa dimensi balas jasa secara negatif mempengaruhi

intensi turnover dan signifikan. Jadi, semakin tinggi skor balas jasa maka semakin rendah intensi turnover.

5. Dimensi penghargaan memiliki nilai koefisien sebesar 0.168 dengan nilai $P$

$=0.136$, yang artinya bahwa dimensi penghargaan secara positif mempengaruhi intensi turnover. Jadi, semakin tinggi skor penghargaan maka semakin tinggi intensi turnover.

6. Dimensi kondisi kerja memiliki nilai koefisien sebesar -0.060 dengan nilai $\mathrm{P}$

$=0.592$, yang artinya bahwa dimensi kondisi kerja secara negatif mempengaruhi intensi turnover. Jadi, semakin tinggi skor kondisi kerja maka semakin rendah intensi turnover.

7. Dimensi rekan kerja memiliki nilai koefisien sebesar 0.172 dengan nilai $\mathrm{P}=0.225$, yang artinya bahwa dimensi rekan kerja secara positif mempengaruhi intensi turnover. Jadi, semakin tinggi skor rekan kerja maka semakin tinggi intensi turnover.

8. Dimensi sifat pekerjaan memiliki nilai koefisien sebesar -0.021 dengan nilai $\mathrm{P}=$ 0.848 , yang artinya bahwa dimensi sifat pekerjaan secara negatif mempengaruhi intensi turnover. Jadi, semakin tinggi skor sifat pekerjaan maka semakin rendah intensi turnover.

9. Dimensi komunikasi memiliki nilai koefisien sebesar -0.193 dengan nilai $\mathrm{P}$ 
$=0.023$, yang artinya bahwa dimensi komunikasi secara negatif mempengaruhi intensi turnover dan signifikan. Jadi, semakin tinggi skor komunikasi maka semakin rendah intensi turnover.

10. Variabel komitmen organisasi memiliki nilai koefisien sebesar 0.029 dengan nilai $P$ $=0.780$, yang artinya bahwa variabel komitmen organisasi secara positif mempengaruhi intensi turnover. Jadi, semakin tinggi skor komitmen organisasi maka semakin tinggi intensi turnover.

Tabel 3

Proporsi Varians Untuk Masing-Masing Independent Variable

\begin{tabular}{|c|c|c|c|c|c|c|c|c|}
\hline \multirow[b]{2}{*}{ Model } & \multirow[b]{2}{*}{$\mathrm{R}$} & \multirow[b]{2}{*}{ R Square } & \multicolumn{6}{|c|}{ Change Statistics } \\
\hline & & & $\begin{array}{l}\text { R Square } \\
\text { Change }\end{array}$ & F Change df1 & & df2 & & $\begin{array}{l}\text { Sig. F } \\
\text { Change }\end{array}$ \\
\hline balas jasa & $.417^{\mathrm{a}}$ & .174 & .174 & 42.601 & 1 & & 202 & .000 \\
\hline komunikasi & $470^{\mathrm{b}}$ & .221 & .047 & 12.161 & 1 & & 201 & .001 \\
\hline upah & $.490^{c}$ & .240 & .019 & 4.987 & 1 & & 200 & .027 \\
\hline penghargaan & $.493^{d}$ & .243 & .003 & .776 & 1 & & 199 & 380 \\
\hline rekan kerja & $.500^{\mathrm{e}}$ & .250 & .007 & 1.833 & 1 & & 198 & 177 \\
\hline atasan & $.504^{\mathrm{f}}$ & .254 & .004 & 1.058 & 1 & & 197 & .305 \\
\hline kondisi kerja & $.506^{\mathrm{g}}$ & .256 & .001 & .375 & 1 & & 196 & .541 \\
\hline komitmen & $.506^{\mathrm{h}}$ & .256 & .000 & .061 & 1 & & 195 & .806 \\
\hline sifat pekerjaan & $.506^{\mathrm{i}}$ & .256 & .000 & .071 & 1 & & 194 & .791 \\
\hline promosi & $.506^{\mathrm{m}}$ & .256 & .000 & .025 & 1 & & 193 & .874 \\
\hline TOTAL & & & .256 & & & & & \\
\hline
\end{tabular}

Dengan demikian dapat disimpulkan bahwa ada 3 IV, yaitu balas jasa, komunikasi dan upah yang signifikan sumbangannya terhadap komitmen organisasi, jika dilihat dari besarnya pertambahan R2 yang dihasilkan setiap kali dilakukan penambahan IV (sumbangan proporsi varian yang diberikan).

Dari table 3 di atas diketahui urutan IV yang signifikan memberikan sumbangan dari yang terbesar hingga yang terkecil ialah upah dengan R2 Change 0.019, komunikasi dengan R2 Change 0.047, dan balas jasa dengan R2 Change 0.174.

\section{Diskusi}

Dari hasil penelitian dan pengujian hipotesis, didapatkan bahwa ada pengaruh yang signifikan dari komitmen organisasi dan kepuasan kerja terhadap intensi turnover. Berikut ini akan peneliti diskusikan hasil pengujian hipotesis lebih lanjut.

Variabel pertama, komitmen organisasi. Dari hasil penelitian terlihat bahwa koefisien regresi yang dimiliki bernilai positif, jadi semakin tinggi komitmen organisasi maka semakin tinggi pula turnover. Hal tersebut bertentangan dengan pendapat Mowday (1982) dimana ia menyatakan bahwa komitmen organisasi merupakan keinginan anggota organisasi untuk tetap mempertahankan keanggotaannya dalam organisasi dan bersedia berusaha keras bagi pencapaian tujuan organisasi. Sehingga 
seharusnya karyawan yang memiliki komitmen yang tinggi akan lebih kecil kemungkinannya untuk meninggalkan organisasi/perusahaannya.

Variabel yang kedua adalah kepuasan kerja. Berdasarkan hasil penelitian yang didapatkan dari variabel kepuasan kerja, hanya tiga tipe kepuasan kerja yang mempengaruhi secara signifikan yaitu dimensi balas jasa, komunikasi dan upah. Saran

\section{Saran Teoritis}

Bagi peneliti yang tertarik dan berminat pada persoalan yang sama, disarankan untuk:

1. Pada penelitian selanjutnya, diharapkan mampu mengembangkan secara baik dan teliti terhadap setiap item yang digunakan, terlebih lagi jika item tersebut merupakan pengadaptasian dari penelitian yang berasal dari luar negeri, telitilah dalam menterjemahkannya.

2. Dalam pemilihan subjek, hendaknya diukur dari berbagai profesi, karena turnover dapat terjadi di berbagai kalangan profesi.

\section{Saran Praktis}

Mengingat pentingnya variabel-variabel yang dapat mempengaruhi intensi turnover karyawan, maka peneliti menyarankan hal-hal sebagai berikut agar perusahaan tidak mengalami kerugian serta dapat mencapai visinya secara efektif dan efisien:

1. Perusahaan memberikan kenaikan upah/gaji yang signifikan, sehingga karyawan akan lebih merasa dihargai dan senang berkerja pada perusahaan.

2. Perusahaan mampu menerapkan sistem komunikasi yang mudah dimengerti oleh karyawan sehingga memudahkan karyawan dalam melaksanakan tugas/pekerjaannya sehingga karyawan akan merasa lebih betah berada dilingkungan perusahaan tersebut.

3. Perusahaan memberikan imbalan yang sesuai dengan pekerjaan yang telah dilakukan oleh karyawan. Imbalan tidaklah dilebih-lebihkan atau dikurangkan, sehingga karyawan merasa bahwa imbalan tersebut diberikan oleh perusahaan karna ia memang pantas mendapatkannya.

\section{DAFTAR PUSTAKA}

Ajzen, I (1988).Attitudes, personality, and behavior. Britain: Open University Press

Ajzen, I (2005).Attitudes, personality, and behavior $2^{\text {nd }}$ edition.New York: Open University Press

Ajzen, I. (2002). Constucting a TpB questionnaire: Conceptual and methodological considerations. Diunduh dari http://people.umass.edu/aizen/pdf/tpb.measurement.pdf pada tanggal17 Juli 2012.

Armitage, C.J., \& Conner, M. (1999) The theory of planned behavior: Assessment of predictive validity and 'perceived control. British journal of social psychology, 38, 35-54. 
Andrews, J.A., Tildesley, E., Hops, H., \& Li, F. (2002). The influence of peers on young adults substance use. Health Psychology, 21, 394-357.

Bachman, J., Wadsworth, K., O'Malley, P., Johnston, L., \&Schulenberg, J. (1997).Smoking, drinking and drug use in young adulthood: The impacts of new freedom and new responsibility. Hilsdale, NJ: Erbaum

Baron, R.A., Nyla R. Branscombe \&Donn Byrne, D. Social Psychology twelfth edition (2008).Boston: Pearson Education, Inc

Chassin, L., Presson, C.C., Pitts, S.C., \& Sherman, S. J.(2000). The natural history of cigarette smoking from adolescence to adulthood in a midwestern community sample: Multiple trajectories and their psychosocial correlates. Health Psychology, 19, 223-231.

Chaplin, J. P. 2006. KamusLengkapPsikologi. Jakarta: PT Raja Grafindo Persada

David, N.B.,\& Zion, U.B (2009).Factors affecting smoking tendency and smoking intensity. Health Education, diambil pada tanggal 25 September 2012 dari journals. htm? articleid $=1784810 \&$ show $=p d f$

http://www.emeraldinsight.com/

De Vries, Brug, Engels, Knibble, Valiccer (2002) On your marks: Revising, testing and integrating stages models of smoking initiation: Universiteit Maastricht

Devi Wulandari(2007) faktor-faktor yang mempengaruhi perilaku merokok dewasa awal Artikel/Th.12/No.2 Fakultas Psikologi Universitas Paramadina: Jakarta

Franzoi, S.L. (2006). Social psychology third edition. New York: McGraw Hill

Fishbein, M \&Ajzen I. (1975).Belief attitude, intention and behavior: An introduction to theory and research. Canada: Addison-Wesley Publishing Company.

Francis, J.J., Eccles, M.P, Johnston, M \& Walker., A,Grimshaw, J. M., Foy,R.,Kaner, E. F. S., Smith, L. \&Bonetti, D(2004). Constructing questionnaires basen on the theory of planned behavior; A manual for health sercives researchers. United Kingdom: University of Newcestle

Gurung, R.A.R, (2006). Health psychology: A cultural approach. Canada: Thomson Wadsworth

Global Youth Tobacco Survey. (2008) diunduh dari www.who.com pada tanggal 28 September 2012

Hurlock, E. (1990). Development psychology. New Tork: McGraw Hill.

Hanan, G. (2001) Global trends in tobacco use. Retrieved June 15, 2012 from http://www.globalink.org/tobacco/wb/wb01.shtml

Harakeh, Z., Scholte R.H.J, Vermulst, de Vries, H., Engels, R.C.M.E. (2004).

Parental factors and adolescents's smoking behavior: An extension of the theory of planned behavior.Preventive Medicine 39 (5), 951-961.

Hasnida \& Indri Kemala (2005). Hubungan atara stres dan perilaku merokok pada remaja laki-laki. Jurnal Psikologi Volume 1 No.2 P S. Psikologi Fakultas 
Kedokteran Universitas Sumatera Utara. Medan: Universitas Sumatera Utara.

Joreskog\&sorbom (1999).Lisrel 8: User's Reference guide. Uppsala University Kaplan, H.I.,B.J. Sadock\& J.A. Greebb. Synopsis of psychiatry, Sinopsispsikiatri: jilid I.Widjaja Kusuma (terj.) (1997). Jakarta: Binarupa Aksara.

Pedazhur, Elazar J. 1973. Multiple regression in behavioral research. New York: Holt, Rinehart, and Winston.

Victoria, P.D., Salgueiro, M.F., Silva, S.S, \&Vries, H.D. (2009).The Impact of social influence on adolescent intention to smoke: Combaining types and referents of influence. The British Journal of Health Psychology, 14,681-699.

Rapeah, M.Y., Muntirah, Y., \&Latifah, O., $K$ Faizah, S.Norsimah, M Maryana, $R$.

Saub (2008). Factors influencing smoking behaviors among male Adolescents in kuantum district.Annual Dent Univ Malaya 15 (2), 77-81. Malaya: Universitas Malaya

Levy, M.R., Digna, M., \&Shirreffs, J.H. (1984).Life and health. United States: Random House, Inc.

Sarafino, E.P. (1990). Health psychology: Biopsychosocial interactions. Canada: John Wiley \& Sons, Inc. 